\title{
Confronting agrarian authoritarianism: dynamics of resistance to PROSAVANA in Mozambique
}

\section{Boaventura Monjane \& Natacha Bruna}

To cite this article: Boaventura Monjane \& Natacha Bruna (2020) Confronting agrarian authoritarianism: dynamics of resistance to PROSAVANA in Mozambique, The Journal of Peasant Studies, 47:1, 69-94, DOI: 10.1080/03066150.2019.1671357

To link to this article: https://doi.org/10.1080/03066150.2019.1671357

\section{Published online: 22 Oct 2019.}

Submit your article to this journal ¿

山ll Article views: 538

Q View related articles $\widetilde{ }$

View Crossmark data \lceil 


\title{
Confronting agrarian authoritarianism: dynamics of resistance to PROSAVANA in Mozambique
}

\author{
Boaventura Monjane (D) ${ }^{a}$ and Natacha Bruna ${ }^{b}$ \\ ${ }^{a}$ Centre for Social Studies, University of Coimbra, Coimbra, Portugal; ${ }^{b}$ International Institute of Social Studies, \\ Erasmus University Rotterdam, Rotterdam, Netherlands
}

\begin{abstract}
This paper explores how varying degrees of authoritarianism and populism, although not always coinciding, have been intrinsic to the imposition of agrarian policies in Mozambique. Taking the case of ProSAVANA, a highly controversial agrarian development program, we look at how its undemocratic imposition by the state has given rise to a vigorous resistance movement. By tracing a decade of electoral results in selected districts where ProSAVANA is intended to be implemented, we argue that due to its agrarian authoritarian policies which have had negative implications on rural livelihoods, the ruling party, FRELIMO, has recently been losing popularity to the strongest opposition party RENAMO.
\end{abstract}

\section{KEYWORDS}

ProSAVANA; Mozambique; authoritarianism; populism; rural resistance

\section{Introduction}

Authoritarianism and undemocratic forms of imposing policies and measures on rural and peasant populations were a norm in colonial and post-colonial Mozambique. This contributed, consequently, to the recurring failures to grasp the nature of the agrarian question ${ }^{1}$ in Mozambique in the context of changing regimes from central planning to market-based development policies (Wuyts 2001). Soon after independence in 1975, Mozambique's dominant political party, Frente de Libertação de Moçambique - Mozambique Liberation Front (FRELIMO), exhibited undemocratic, and to some extent populist, characteristics with regards to implementing agrarian policies. In the current neoliberal period, however, FRELIMO's regime has come to clearly exercise varying and decreasing degrees of populism combined with authoritarianism when it comes to choosing and imposing agrarian policies. The Triangular Co-operation Programme for Agricultural Development of the Tropical Savannah in Mozambique Project (hereafter referred to as ProSAVANA), is one concrete example.

CONTACT Natacha Bruna natachabruna89@gmail.com $\theta$ International Institute of Social Studies, Erasmus University Rotterdam, Rotterdam, Netherlands

Editorial Note: This paper is part of the 'JPS Forum on Authoritarian Populism and the Rural World', framed and introduced by lan Scoones and colleagues in their joint paper, 'Emancipatory Rural Politics: Confronting Authoritarian Populism', published in JPS in January 2018. The contributions to this forum will be published separately and in clusters in 2018 and 2019. This forum is one of the initial outcomes of the activities of the Emancipatory Rural Politics Initiative (ERPI, www.iss.nl/erpi).

${ }^{1}$ The agrarian question approached in this paper goes in line with the classic definition provided by Byres (1991, 9) where the continuing existence of poverty - and its political consequences - in the country side alongside with substantive obstacles to generate economic development both inside and outside agriculture. 
ProSAVANA was first introduced in the beginning of the 2010s, as a developmental project in line with the main agrarian policy of Mozambique, the Plano Estratégico para o Desenvolvimento do Sector Agrário (PEDSA - Strategic Plan for the Development of the Agrarian Sector), which aimed to transform the agricultural sector to be more investment and business-friendly (RM 2011). To this end, the main objective of ProSAVANA has been to increase agricultural productivity, targeting 11 million hectares in north-central Mozambique, targeting areas in Niassa, Nampula and Zambézia provinces, a region known as the Nacala Corridor. Importantly, ProSAVANA was initiated and implemented by the Mozambican Ministry of Agriculture and Food Security (MASA), the Brazilian Cooperation Agency (ABC) and the Japan International Cooperation Agency (JICA).

Public disclosure of the Master Plan quickly sparked resistance. This was largely due to the apparent lack of transparency and inclusivity in the planning process, and the apprehension coming from knowledge of the negative impacts of PRODECER, a large scale agricultural development project in Brazil, in the late 70's of the last century (we develop more on PRODECER later). The emergence of a transnational campaign, called 'Campanha não ao ProSAVANA - No to ProSAVANA Campaign' (hereafter referred to as NPC), came to be central to the resistance process. NPC presented an organized and explicit contestation to not only the ProSAVANA project itself, but the fundamental paradigm of rural development promoted by the project. Parallel to the constitution of the campaign and the resistance movement, FRELIMO was losing electoral support in the region where ProSAVANA is due to be implemented, the Nacala Corridor. The NPC, while demanding the discontinuation of ProSAVANA, also proposed alternatives to rural and agricultural development. This effort not only led to the current 'hibernation' of the project but created space to enable expanded participation of peasants and civil society throughout the decision-making process.

\subsection{Key questions and structure of the paper}

This paper analyses the process and dynamics of resistance to ProSAVANA as a way of confronting authoritarian imposition of agrarian policies in Mozambique. The main objective is to explore how the varying political regimes and their varying degrees of populism and authoritarianism contribute to the triggering of resistance, particularly looking at how and why the NPC was able to 'succeed' in hibernating ProSAVANA. The paper gives an explanation on how a combination of five elements, in the right timing regarding FRELIMO's popularity and support, were strategically determinant in putting the program on hold: (1) political reactions from below, (2) intersectoral civil society alliance, (3) communication, outreach and media strategy, (4) transnationalization of the struggle, and (5) the proposal of alternatives to dominant narratives. Although these five tactics were strategically executed, opponents of ProSAVANA were sharp in maximizing the existing generalized rural discontent. The decrease in rural votes for FRELIMO across the Nacala Corridor was not an accident, but a result of FRELIMO's strategy and policies on rural development as the paper demonstrates further. 
The paper is organized into five main sections. Following Section 1, the Introduction, Section 2 briefly approaches the conceptualization of authoritarianism and populism, and its relation to Mozambique. This section also explores the presence of authoritarianism throughout the inception and early implementation of ProSAVANA. Section 3 examines ProSAVANA: what are its main goals, its components, deficiencies as well as contradictions. Section 4 directly addresses how ProSAVANA was confronted, highlighting the role of the National Peasant Union (UNAC) in the NPC. Lastly, Section 5 has concluding remarks.

\subsection{Methods and methodology}

This paper is based on data collected from a combination of methods during fieldwork conducted intermittently between 2014 and 2018 in the capital city of Maputo, and in the provinces of Nampula and Zambézia. Unstructured (open) and semi-structured interviews were conducted throughout and directed to multiple stakeholders, such as peasants, peasant union representatives, organizations affiliated with NPC, government officials at district and province levels and ProSAVANA representatives at the provincial level.

Additionally, participant observation was conducted, including participating in public hearings both at district and national levels, visiting ProSAVANA's pilot-projects sites and participating in meetings with the Mozambican civil society at the international, national, provincial and district levels. Lastly, analysis of secondary sources on ProSAVANA - both officially and un-officially (leaked) disclosed documents, public statements and government strategies - was held. Such activities were reinforced by extensive first-hand foundational knowledge by one author who had worked as a staff member of UNAC between 2009 and 2015.

The qualitative primary data was processed through transcription of the interviews and field notes. The body of empirical data was then analyzed using process tracing in order to trace the links between possible causes and observed outcomes (Bennett and George 2005). Validation of preliminary conclusions was conducted in September to November 2018, where the authors discussed their main findings with NPC members.

Table 1. Percentage of total votes per district (elections of 2008 and 2018).

\begin{tabular}{|c|c|c|c|c|c|c|c|}
\hline \multicolumn{2}{|c|}{ Votes per region } & \multicolumn{3}{|c|}{ FRELIMO } & \multicolumn{3}{|c|}{ RENAMO } \\
\hline Province & District & 2008 & 2013 & 2018 & 2008 & 2013 & 2018 \\
\hline \multirow[t]{3}{*}{ Niassa } & Lichinga & 75 & 66 & 51 & 23 & $\mathrm{n} / \mathrm{a}$ & 45 \\
\hline & Cuamba & 77 & 70 & 39 & 16 & $\mathrm{n} / \mathrm{a}$ & 53 \\
\hline & Marrupa & 95 & 91 & 71 & 4 & $\mathrm{n} / \mathrm{a}$ & 18 \\
\hline \multirow[t]{3}{*}{ Nampula } & Nampula City & 69 & 44 & 32 & 28 & $\mathrm{n} / \mathrm{a}$ & 59 \\
\hline & Ribaue & 87 & 72 & 46 & 11 & $\mathrm{n} / \mathrm{a}$ & 42 \\
\hline & Monapo & 62 & 70 & 47 & 37 & $\mathrm{n} / \mathrm{a}$ & 46 \\
\hline \multirow[t]{3}{*}{ Zambézia } & Quelimane City & 55 & 33 & 36 & 43 & $\mathrm{n} / \mathrm{a}$ & 59 \\
\hline & Alto Molocue & 67 & 53 & 48 & 31 & $\mathrm{n} / \mathrm{a}$ & 47 \\
\hline & Mocuba & 73 & 52 & 50 & 24 & $\mathrm{n} / \mathrm{a}$ & 45 \\
\hline
\end{tabular}

Notes: In 2013 Renamo boycotted the municipal elections; contestation of electoral processes and previous results were among the different reasons presented by the party leader Afonso Dhlakama.

Source: Comissão Nacional de Eleições (2018) and WLSA Moçambique (2014). 


\section{Authoritarianism, populism and coercive rural policies in Mozambique}

The discussion about authoritarian populism emerged from Poulantzas' discussions on 'authoritarian statism', which was defined as the increase of state control regarding every aspect of economic life, accompanied by a decrease in democracy (Hall 1980). Hall took the concept one step further, identifying 'the set of operations designed to bind or construct a popular consent into these new forms of statist authoritarianism' (Hall 1980, 161), terming it 'authoritarian populism'. The concept emerged from a reflection on the construction of popular consent 'by a historical bloc seeking hegemony, as to harness to its support some popular discontents, neutralize the opposing forces, disaggregate the opposition and really incorporate some strategic elements of popular opinion into its own hegemonic project' (Hall 1985, 118).

Scoones et al. (2017) reintroduced and further explored the concepts of 'populism' and the rising worldwide phenomenon of 'authoritarian populism' within current contexts in the countryside. Nevertheless, in Southern Africa, populism is generally associated with liberation movements that secured political power as governments, using populist stand as a means to legitimize their power by appealing to the continued struggle against foreign domination and thereby marketing themselves as the only true political alternative. When contested politically, they accuse opponents of being remote-controlled agents of imperialism seeking regime change as instruments of foreign agendas (Melber 2018).

Populism is largely a reaction to social dislocations tied to processes of neoliberal globalization (Hadiz and Chryssogelos 2017). What seem to be a common ground among political and state elites in the region is the push for neoliberal agendas in various sectors applying populist strategy and at times authoritarianism. There has been an increase in reactionary politics in some societal sectors in the region, to promote neoliberal neoclassic values and visions. ProSAVANA, as we argue, fits in this trend. If on the one hand ProSAVANA was imposed authoritatively, resistance to it took, in part, progressive populist forms. Some would contest the term 'populist' when referring to progressive approaches and instead use 'popular' (Shivji 2019).

Borras $(2019,3)$ furthers the discussion of Scoones et al. (2017) by defining populism as 'the deliberate political act of aggregating disparate and even competing and contradictory class and group interests and demands into a relatively homogenized voice, i.e. "us, the people", against an "adversarial them" for tactical or strategic political purposes'.

Borras (2019) distinguishes populism into two types: a right-wing populism, the one that has disdain for democratic institutions, and a more progressive type of populism, namely agrarian populism. Although he uses the term 'right-wing populism' as a proxy for authoritarian populism, he still questions the more fitting term to this concept among the ones used. He conceptualizes agrarian populism as the political bundling of anti-capitalist rurally-based or rural-oriented social groups advocating for a peasant way of alternative development.

Most notably, Borras (2019) describes that the crucial point of analysis is not whether a specific regime is populist or not, but the degree to which the regime is populist. In other words, to what extent is a regime, regardless of its authoritarian nature, populist. It can 
therefore be conjectured that a regime dynamically oscillates between varying degrees of populism and a persistent high level of authoritarianism throughout time. Evidence of this dynamic can be clearly observed through careful analysis of the historical trajectories characterizing rural Mozambique.

O'Laughlin $(1996,5)$ summarized post-independence strategies of agrarian transition in three phases:

The first phase, from 1975 to 1980, was defined by broad-ranging political consensus around the need for a rapid socialization of production and residence through the expansion of statefarms, co-operatives, and communal villages. The second highly contradictory phase, from 1980 to 1983, was defined by FRELIMO's shift to a bureaucratic and hierarchical model of rapid socialist accumulation based almost exclusively in state farms. Goods starvation in rural areas, the stagnation of state farm production, and widening support for the RENAMO opposition movement from South Africa (amongst others) led to a rapid expansion of both the war and parallel markets in rural areas. FRELIMO's strategy in the third phase, beginning with the Fourth FRELIMO Party Congress in 1983, was initially defined as market socialism, but moved rapidly towards increased support for private commercial farming, and the distribution of some state farm land to multinational enterprises, Mozambican commercial farmers and some peasant households.

The first phase referred to by O'Laughlin (1996) is parallel to FRELIMO's rise as the protagonist of the national liberation from colonial rule, as its name itself portrays ('Frente de Libertação Nacional' - National Liberation Front). They showed themselves as the symbol of national resistance, as revolutionary and a savior of the people, winning back the control of the country for the Mozambican people. FRELIMO was represented in the national anthem as 'the guide of Mozambican people' and portrayed, in the 1975 constitution, as 'the leading force of the State and Society'. Additionally, the presence of a charismatic and visionary leader, namely Samora Moisés Machel who served as the first president after independence, who believed in socialist principles, leading the discourse on social change and justice was essential in the attempt to build a positive image for FRELIMO.

Authoritarianism and undemocratic forms of imposing policies and measures taken on rural and peasant populations were a norm in colonial Mozambique. Soon after independence in 1975, some of FRELIMO's agrarian policies exhibited undemocratic characteristics. For example, from a historical perspective, we can refer to the agrarian policies implemented by the revolutionary government of the People's Republic of Mozambique, FRELIMO, namely the aldeamentos comunais (villagization) or the communal village policy, which took similar measures as aldeamentos coloniais, the colonial villages.

Established in 1968, the colonial villages were believed to have been created as a mechanism to monitor and control rural populations, mostly to avoid contact with FRELIMO, the national revolutionary forces at the time (Coelho 1998). The colonial villages were

(...) based on a preventive philosophy, sought to bring people together in villages that would enable social progress and, at the same time, avoid contact with subversion, so that they would not be 'contaminated'. (Garcia 2001, 130)

On the other hand, FRELIMO's communal villages aimed to organize a dispersed peasantry in the form of villages. This, however, was also understood as a measure taken to control the peasantry, preventing the population from gaining access to and receiving influence 
from the Resistência Nacional de Moçambique (RENAMO), the anti-FRELIMO government guerrilla group. Assuring FRELIMO to maintain hegemony over the peasantry.

There is a consensus among scholars on the idea that implementation of the communal village policy was directly inspired by the colonial villages (Coelho 1998; Garcia 2001; Lourenço 2010; Monjane 2016a). The majority of communal villages were simply conversions of the old colonial village settlements. Vitor Lourenço (2010) demonstrates how the colonial Portuguese settlements along the main road connecting Mandlacaze and Panda districts in southeastern Mozambique, were simply renamed, with few organizational modifications, when converted into communal villages $(2010,178)$. FRELIMO was equally criticized as being 'interventionist, authoritarian, and coercive for engaging in projects that belittled customary African practices, forcibly relocating people, or threatening the livelihoods of the peasantry' (Pitcher 2012, 19).

FRELIMO and Samora's discourse was explicitly critical of colonialism, and later on, of the emerging opposition movement (RENAMO). These political discourses consistently included divisive narratives of 'us' against 'them', in which the 'other' changed faces from colonialism to the scourge of colonialism, in the form of 'armed bandits', the RENAMO. Scoones et al. (2017) point out that authoritarian populism is based in depicting politics as a struggle between the people and 'others'. In this case, it would be FRELIMO against colonialism, or FRELIMO against RENAMO. This was the foundation for the construction of FRELIMO's authoritarism and populism. In this context, Mosca $(2005,137)$ stated that 'Overall, FRELIMO structured society and power based in an authoritarian one-party system, with an ideology that combined populist and orthodox leftist features'.

Going back to O'Laughlin (1996), the third phase was characterized by a process of massive privatization, in the name of economic rehabilitation, supported by the Bretton Woods Institutions. This was represented by the emergence of a market economy in Mozambique, in what was now called a 'democratic' society. The societal acceptance of FRELIMO as the nation's rescuer, sustained through the stigmatization of those who are against it, helped to maintain FRELIMO's populism both in rural and urban areas. Although it has been the ruling party since independence, RENAMO has been systematically contesting and questioning election outcomes, occasionally succeeding in proving irregularities in the processes. Nevertheless, the enduring legitimization of FRELIMO's dominance was a clear feature of authoritarian populism (Hall 1985; Scoones et al. 2017).

We expand our analysis and include the current processes of forced displacement of rural populations (specially the peasantry) from their areas of residence and cultivation to resettlement zones (reassentamentos) as a continued state policy of coercive, and therefore authoritarian and undemocratic, regrouping of rural populations in Mozambique (Monjane 2016b).

Throughout history, FRELIMO showed patterns of an authoritarian populist party with relatively high support in the countryside of some provinces due to its role as the revolutionary force and savior of the people. Nevertheless, in the current neoliberal period, we understand FRELIMO's regime as exercising a combination of dynamically changing expressions of populism and persistent presence of authoritarianism when it comes to selecting and imposing agrarian policies. 


\section{Authoritarism in pushing market-oriented agricultural development: the imposition of ProSAVANA ${ }^{2}$}

Nowadays, FRELIMO does not always have the supportive base to exercise its populist character. In reality, Frelimo's popularity has been falling throughout the years. Two main reasons might partially explain the decadence of this very important strategy of the dominant political party in the last decades: (1) colonialism per se is no longer an issue and RENAMO no longer represents a 'threat' to the well-being of the people, which results in the inexistence of a powerful external/internal enemy in the discourses as there is no longer a clear 'other' to blame for ${ }^{3}$; $(2)$ the emergence of a intense feeling of frustration and discontent after decades of authoritarian agrarian policies, adopted and implemented by the government, resulted in land conflicts between capital and the peasantry, localized intensification of poverty and political and military instability; consequently, different segments of the rural and urban population no longer feel represented nor identify themselves with FRELIMO's claims and discourses.

So, Table 1 shows the patterns of electoral votes and the reflection of a loss of popularity by the dominant political party in selected regions. To understand the fall of FRELIMO's popularity, we chose to analyze the results from the most recent elections (municipal elections of 2018) which shows the most recent picture of the manifestation of 'revolt' at the ballot box. The 2008 and 2013 elections happened in a period of time in which the penetration of capital in rural areas started to have major implications - especially related to land grabbing to accommodate resource extraction such as Vale de Moçambique and the whole complex of multinationals investing in coal extraction in Tete province since 2009. So, the ratio Investment/GDP shows an increasing tendency from 2008 to 2018, with a maximum registered in 2014 when total investment represented $55 \%$ of the GDP (Instituto Nacional de Estatística 2018). At the national level, the agriculture sector as well as in the 'mineral resources and energy' sector hosted the highest amounts of approved investment in cumulative terms, from 2001 to 2017 (CPI 2017). At the provincial level, investment trends show that Nampula is the second province in the country with the highest amount of approved investment inflow from 2001 to 2017, with cumulative investment of more than 9 billion USD (CPI 2017).

In the table below, we only put forward provinces that were targeted by ProSAVANA. Within each province, we selected three main districts, including the capital of the province, and two essentially rural districts. Additionally, we considered the size of the population (chose most populated areas) and areas in which ProSAVANA's activity/investment/ resistance have taken place; but, of course, limited by the availability of data regarding the selected period of election.

As mentioned previously, land conflicts that arose as a result of capital penetration in the countryside were a major issue of contestation within the rural population. The imposition of land-based agricultural investments in specific regions of the country resulted in the expropriation of people's land, especially throughout these three provinces. A number of companies expropriated hundreds of thousands of hectares from local peasants and

\footnotetext{
${ }^{2}$ Detailed analysis of ProSAVANA's discourses, objectives and Master Plan Zero can be explored in the following papers: Funada-Classen (2013a, 2013b), Clements and Fernandes (2013) and Mosca and Bruna (2015).

${ }^{3}$ However, Frelimo Government has been targeting confrontational civil society organizations, throwing unfounded accusation that they serve obscure interests and are external agents.
} 
consequently, a lot of people were displaced. In Zambézia province, Gurué district, by 2017, Portucel Mozambique had occupied the land of more than 2,000 households; in the same district, Hoyo Hoyo expropriated the land of about 800 families (Mandamule and Bruna 2017); in Wakua (in the border area between Nampula and Zambézia) Agribusiness de Moçambique SA, Agromoz, forced the displacement of approximately 1,000 families (Mandamule and Bruna 2017); in Malema district (Nampula province) Mozambique Agricultural Corporation, Mozaco, also forced the displacement of about 1,000 families (UNAC and GRAIN 2015).

In the same period, debates around the implementation of ProSAVANA emerged. The imposition of ProSAVANA as the most important policy for the Nacala Corridor initiated in the 2010s. As previously mentioned, ProSAVANA was drafted, initiated and implemented in a top-down manner. Guidelines, strategies and specific activities were mostly defined by the Ministry of Agriculture (led by José Pacheco, the Minister at the time), along with its Brazilian and Japanese partners, the Brazilian Cooperation Agency (ABC) and the Japan International Cooperation Agency (JICA). Preparatory activities were already taking place even before the Master Plan was published, without the information provided or consultation with the population of people who are to be directly and indirectly affected.

The ProSAVANA programme, from the beginning, was neither conceived together with the local inhabitants nor was there interest in meeting local needs. Instead, this project was conceived as a way for Japan and Brazil to: work together for achieving UN reform, participate in the new global political/economic structures such as BRICS and G20, and jointly promote commodity production/extraction. (Funada-Classen 2013b, 3)

Despite the Mozambican legislation (specifically the Land Law 19/1997, Decree 31/2012 of resettlements and Law of access to information 34/2014) clearly stating the need for public consultation and consent throughout the process of planning and implementation of any projects requiring the use of land ${ }^{4}$ It was only after public protests and political pressure calling for a more inclusive and transparent process from Mozambican, Brazilian and Japanese civil society that JICA and the Mozambican Government decided to engage in public hearings and consultations throughout the whole target region.

A joint statement published by Civil Society Organizations (Comboni Missionaries 2015), which participated in such public hearings, described the authoritarian character of ProSAVANA's implementation process very clearly. Issues brought up included the belated announcements of the date, time and location for the public hearings, citing an incident when only a couple of weeks' notice was given. This compromised people's access to information, which directly lead to limiting the presence of stakeholders at the hearings. Another issue was how the public hearing process did not cover all of the targeted regions in ProSAVANA. Where public hearings were held, the time was mostly spent on announcements, rather than on open discussion. The hearings predominantly focused on optimistic representations of ProSAVANA, without any mention of social, economic or environmental risks. Questions raised by the public were not fully answered. And

\footnotetext{
${ }^{4}$ For specific cases of acquiring land, community consultations are the first step to be taken. These community consultations or hearings are a legislated form of public participation that ought to be conducted before the implementation of a project or investment as a way to get the 'community' sensibility regarding the plan of investment and consent regarding the use of land (No 3, Article 13 of Land Law 19/1997). In case of reaching community consent to transfer the land to the investor/project, four public consultations are needed to plan and implement the resettlement process of the people who agreed to transfer their land (Article 23 of Decree 31/2012 of Resettlements).
} 
lastly, the presence of an armed policeman in the room suggested the potential to suppress any divergent opinions or positions.

These findings are corroborated by Mosca and Bruna (2015) who report on a public hearing for ProSAVANA that took place on the 12th June in 2015 in Maputo. This gathering was moderated by the then Minister of Agriculture himself, who clearly stated how 'all of the interventions during the debate must be "patriotic". Do not come here with obscurantist agendas'. He further goes on to state his firm commitment for the mission, by stating 'If there is any obstacle, we will run over it and move on with our mission' (Moçambique para todos 2015; Monjane 2015; Mosca and Bruna 2015, 25-26). Mosca and Bruna further highlighted the under-representation of peasants in the meetings and the dominant presence of public workers such as teachers, nurses and the police. Moreover, they report on the accounts of people who were threatened after protesting or showing opposition to the ideas presented in the public hearing (Mosca and Bruna 2015).

As we argue in this paper, ProSAVANA was introduced with a great degree of authoritarianism and sometimes with elements of populism. We demonstrate further that the strategy of its opposition had visible characteristics of agrarian populism.

\subsection{What is ProSAVANA?}

ProSAVANA's stated aims are to boost agricultural and rural development, targeting an area covering approximately $13 \%$ of the country and $17 \%$ of the total population. The area is referred to as the Nacala Development Corridor, ${ }^{5}$ which lies in a uniquely fertile region, also famous for its endowment of mineral resources. The region also includes the deepest sea port in East Africa, strategically located to allow easy access to Asian markets. This government-led program follows most of the guidelines recorded in Mozambique's Strategic Plan for the Development of the Agrarian Sector (PEDSA). The first drafts of ProSAVANA's Master Plan were written by consultants and experts from JICA, Brazilian Agricultural Research Corporation (Embrapa), FGV and the Mozambican Institute of Agricultural Research (IIAM).

Shankland and Gonçalves (2016), Funada-Classen (2013a), among others assume that ProSAVANA was initially inspired by PRODECER, a Japanese-Brazilian Cooperation Program for the Development of the Cerrado of Brazil. The program began with a joint statement to establish a relationship between the two countries on agricultural development, signed by then Japanese Prime Minister, Kakuei Tanaka, and then President of Brazil, Ernesto Geisel, in September 1974 (Inocêncio 2010). Official project documents regarding ProSAVANA commonly emphasize the biophysical and geographic similarities between the Cerrado and Nacala Corridor as well as their position as centers of economic and political power. Wolford and Nehring (2015), however, emphasize the differences between the two nations, highlighting key differences in the commodification processes of land and labor with relation to capital.

The Mozambican civil society only heard of ProSAVANA after Brazilian media reported on Mozambique giving away extensive farm land for Brazilian soy production (Mello 2011),

\footnotetext{
${ }^{5}$ Connecting Malawi, Zambia and Mozambique up to Nacala Port, located on the coast of the Indian Ocean (approximately $700 \mathrm{~km}$ ), the Nacala Corridor is one of the six logistic corridors assigned for the implementation of PEDSA and the target for the implementation of ProSAVANA (MASA 2015).
} 
drawing reference to 'Brazil's successful experience'. Detailed information about the project was only revealed to the public after a draft copy of the ProSAVANA Master Plan was leaked in 2013. In a joint statement, a group of Mozambican and foreign civil society groups denounced the project, stating that it 'confirms that the governments of Japan, Brazil and Mozambique are secretly paving the way for a massive land grab in Northern Mozambique' (Justiça Ambiental et al 2013, 1).

An official unclassified powerpoint presentation from the Joint Coordination Committee (JCC) of ProSAVANA was also revealed to Mozambican civil society. Some points highlighted included 'Land Reserve for Investment' and 'Development of Agribusiness' (JCC 2012). Moreover, potential infrastructure development of the Nacala Development Corridor included the renewal of the Nacala Port - the countrýs deepest port - and the Nacala Railway. The leaked documents confirmed that the main goal of ProSAVANA was to prioritize agribusinesses, promote monocrop production and exports of cash crops (such as soy). Furthermore, all of the activities targeting small to medium scale farmers were related to financialization schemes, which JCC (2012) called 'financial support systems', directly associated with their ability to hold land titles.

\subsection{Components of ProSAVANA}

The official document of ProSAVANA, namely 'Master Plan Zero' was published by MASA (Ministry of Agriculture and Food Security) in March 2015. Included are three components: (1) ProSAVANA - PD (Plano Director or Master Plan) that introduces the main guidelines through which the overall agricultural sector would be improved and modernized, (2) ProSAVANA PI (Projecto de Investigação - Research Project) which refers to the intensification of research and technology transfer, and (3) the ProSAVANA PEM (Models of Extension Project) that aims to improve extension activities (MASA 2015).

Under ProSAVANA 'fast impact' pilot projects, some medium to small-scale private companies and peasant associations received credit inflows to develop activities that answered to ProSAVANA's Master Plan guidelines. One of the investing companies, in an attempt to implement the financed project in the Ribaué District, encountered several families that were already established in the area. The area included houses and plots that had been there for more than 10 years; consequently, a land conflict emerged. Even though Article 12 of the Land Law confirms that the land in question belonged to the rural households (since they have been living on those plots for more than 10 years), they were displaced. This process resulted in the expropriation of land, and a loss of houses and cultivated plots.

According to the Director of the Institute of Agrarian Research in Nampula Province, ${ }^{6}$ the main activities carried out under ProSAVANA PI included research related to cultivation systems and transfer of technology, testing and introduction of varieties, institutional training, and soil improvement. However, the main target was to introduce and spread the production of soy, in order to feed Mozambique's chicken value chain. In other words, a lot of effort was put into the production of a crop that was not going to directly benefit the local economy nor the diet. Even if it were available, households were not familiar with the crop, nor did they have the knowledge or the means to process it into food.

${ }^{6}$ Interview, Director of the Institute of Agrarian Research in Nampula Province, April 2015. 
In relation to ProSAVANA PEM, during fieldwork activities, the authors identified and visited two peasant associations (Maria da Luz Guebuza and Namuáli) that received financial support in order to receive a motor pump. While it was intended to be shared, since the machine was too heavy to carry from one location to the other, only one association, the bigger one, got the opportunity to use and benefit from the pump. What resulted was the poorest association ending up with nothing but a debt.

\subsection{ProSAVANA deficiencies, contradictions and the Nacala fund}

ProSAVANA's Master Plan is far from comprehensive, beginning with the incomplete explanation of their financial resources. The initial discussions regarding the cooperation between Brazil, Japan and Mozambique in the Nacala Corridor required the creation of the Nacala Fund. According to Fundação Getulio Vargas (FVG), ${ }^{7}$ the institution which was supposed to manage this fund (specifically in the FVG Projects branch), this was an initiative from FGV, ABC, JICA, Embrapa, FAO, Chamber of Commerce and Industry Brazil-Mozambique, Mozambican Ministry of Agriculture, and 4I. GREEN.

According to FGV, the main objective of the fund was to finance projects that stimulate agricultural development in the Nacala Corridor (FGV 2012), including ProSAVANA. However, throughout the implementation of ProSAVANA pilot-projects and even after the program's hibernation period, it was never made clear how FVG was managing and applying for funds, much less what FGV was planning to do with it in the future. Nevertheless, the Master Plan presents a very brief summary of a preliminary ProSAVANA budget of 9.371.000.000,00 Meticais (or USD133.871.430,00 using an average current exchange rate of 70Mts/USD) (MASA 2015).

The Nacala Fund issue suddenly vanished from official discourses and documents on ProSAVANA after being criticized by civil society for being the main financing vehicle for the big agribusiness projects in the Nacala Corridor. It was revealed that the fund would be registered in the fiscal paradise of Luxembourg (Justiça Ambiental, et al. 2013, 2-3). A ProSAVANA representative in Nampula said however that the idea of the Nacala Fund was introduced by a third party, external to the main ProSAVANA initiatives. ${ }^{8}$

After resistance, there were significant changes in a later version of the Master Plan Zero of 2015. This version attempted to be more inclusive, for example, through the use of 'agroecological' language, mentioning local markets and small to medium scale models of agriculture. Regardless, the response from civil society emphasized how, fundamentally, the text maintained its vision to promote businesses, maintaining the same outlook. This can clearly be inferred from the fact that the revised Master Plan Zero of 2015 did not mention a mechanism for securing land use and access for peasants in the proposed areas.

Mosca and Bruna (2015) further identify gaps in ProSAVANA's Master Plan Zero of 2015: they include (1) not providing resettlement processes or mechanisms to assure that it can be conducted in a fair and sustainable manner while maintaining or improving the quality of lives in communities; (2) not being clear about its environmental, social and economic impacts; (3) being overly optimistic about the capacity of the Government to effectively

\footnotetext{
${ }^{7} \mathrm{FVG}$ is a private higher education institute which, according to their mission, aims to develop and disseminate knowledge in the field of public and private businesses.

${ }^{8}$ Interview with Américo Uacequete, Nampula, February 2017.
} 
support a program of this dimension; (4) predicting a fall in the overall contribution of the agricultural sector to the regional GDP (from 42\% in 2011 to 24\% in 2035), while forecasting an increase in the mineral sector; (5) not reflecting the needs, priorities and aspirations of the peasants; and (6) ignoring possible conflicts between the traditional models and systems of agricultural production and the model presented by ProSAVANA.

In sum, it is clear that the initial effort to implement ProSAVANA has been one that distinctly supports the expropriation of land, the intensification of debt among peasants, and the promotion of crops that do not meet the people's needs. In other words, ProSAVANA's model does not respect customary rights. It marginalizes the needs and aspirations of the peasant and rural populations. As a result, the project fosters higher levels of vulnerability in communities, furthering conflicts and a deepening levels of poverty and food insecurity. This stems from a complete deviation from constitutional rights, land legislation and the constitutional principle of legal pluralism, which states that customary laws should be respected.

Beginning with the lack of transparency and limited participation throughout the entire planning process, combined with the model of development and the guidelines proposed in the Master Plan, ProSAVANA was a wake-up call for the Mozambican National Peasant Union. It resulted in civil society groups of Mozambique, Brazil and Japan joining efforts to initiate and articulate a resistance, based on apprehension for serious social, economic and environmental impacts, mainly surrounding land expropriation of peasants. Such concerns resulted in the formation of the Campanha Não ao ProSavana 'No to ProSAVANA Campaign' or NPC.

\section{Confronting agrarian authoritarianism}

\subsection{The rise of the 'no to ProSAVANA campaign': an agrarian 'populist' confrontation}

Before the launching of the NPC, there were a number of noteworthy actions taken by civil society organizations, led by the National Peasant's Union (União Nacional de Camponeses) or UNAC. Perhaps, the most significant was an open letter addressed to the governments of Brazil, Japan and Mozambique, sent in in May 2013. The letter protested the lack of an inclusive and transparent public discussion concerning ProSAVANA's environmental, social and economic impacts (UNAC et al 2013). The letter was signed by 23 Mozambican organizations and supported by 43 international organizations. The prolonged silence of the three governments following the letter was what triggered the formation of the NPC a year later.

The NPC was launched in June 2014, initially with nine-member organizations: UNAC; the Rural Association for Mutual Aid (ORAM); the Mozambican Human Right League; Fórum Mulher and World March of Women; Justiça Ambiental (Environmental Justice); Livaningo; Academic Action for the Development of Rural Communities (Acção Académica para o Desenvolvimento das Comunidades Rurais, ADECRU); Archdiocesan Commission for Justice and Peace of Nampula (Comissão Arquidiocesana de Justiça e Paz de Nampula); and lastly, gained strong support from the Mozambique Bar Association (Ordem dos Advogados de Moçambique). NPC's main objective was clear: To disable and terminate all ongoing activities and projects related to the ProSAVANA program (ADECRU 2014). 
In a statement read during the launching of the NPC, the proponents stated the nefarious and devastating impact that this program would potentially bring to thousands of peasant families residing in the Nacala Corridor. It was added that ProSavana does not represent a solution for Mozambican agriculture, but is simply a solution to meet Japan and Brazilian soy needs (ADECRU 2014). In an interview with the authors, the Director of UNAC stated:

Firstly, we heard about it (ProSAVANA) through the newspaper Folha de São Paulo that talked about the Minister's intervention regarding the perspective of the development of a program in Nacala Corridor, which had already been developed in Brazil ... This raised some questions among us. For us, the Nacala Corridor is the corridor for food production and supply for the entire area ... and we realize that with the implementation of ProSAVANA, we are going to have serious issues. So, we asked that a group (UNAC and ORAM) go to Brazil to investigate this type of development model. The information received was that it is not worth it. ${ }^{9}$

The uniqueness of the NPC was the assemblage of groups working on diverse issues: agrarianism, gender and feminism, human rights and legalism, environmentalism, faith and academic, unifying in order to defend a particular agrarian cause.

The NPC kept on incorporating more members from diversified sectors within Mozambique, but then started to extend their alliance to the Brazil Agrarian Movements and NGOs, as well as Japanese activists and academics. The campaign soon became a transnational movement.

As JICA was intensifying its support for ProSAVANA, in 2017, members of the NPC sent an open letter to its President, demanding an immediate suspension of JICAS's actions in ProSAVANA. In addition, they called for a revision of JICA's approaches, an acknowledgement of their mistakes, and compensation to repair the damages already caused to victims of the program in Mozambican society (Monjane 2017).

\subsection{Actions, strategies and fragmentation}

The NPC's strategy has consisted of an overt and organized contestation of specific projects mandating a model of rural development. The actions were specifically targeted at the Mozambican government (Ministry of Agriculture, later Ministry of Agriculture and Food Security), alongside advocacy targeting the Japanese and Brazilian governments.

Public strategic meetings, such as the 'Triangular Peoples Conferences', the most recent in November 2018 in Japan, were held. ${ }^{10}$ Some of the actions included occupying public spaces (such as holding protests) and issuing statements and open letters to be used as materials for recurrent tactics. UNAC members in Nampula and Zambézia provinces strategically mobilized citizens to oppose ProSAVANA through regular field visits and meetings with the peasantry living in these provinces.

As the proponents of ProSAVANA continued to face resistance, tactics were used to fragment and isolate opposition. This was done through a voting system which consisted

\footnotetext{
${ }^{9}$ Interview, Luís Muchanga, Director of UNAC, member of NPS campaign, 30 August 2018.

${ }^{10}$ So far, four Triangular Peoples Conferences were held, the first three in Maputo, Mozambique. These conferences bring together peasants (UNAC members) from Nampula, Zambézia, Niassa and Cabo Delgado provinces, activists from NPC member organisations, members of government (i.e, the Ministry of Agriculture himself), academics and members of the press.
} 
of asking which organizations were open to working on revising ProSAVANA PD (Chichava 2016).

This eventually resulted in the fragmentation of Mozambican civil society into two factions: the pro- and anti-ProSAVANA. Those who support the vision of the Master Plan organized themselves into the Mecanismo de Coordenação da Sociedade Civil para o Desenvolvimento do Corredor de Nacala (Civil Society Coordination Mechanism for the Development of the Nacala Corridor), or MCSC-CN. The MCSC-CN has since been officially recognized by MASA as its legitimate interlocutor in issues regarding ProSAVANA. This was justified by the fact that most of the MCSC-CN members are based, or are working in, Nampula and Zambézia provinces. MCSC-CN has not integrated local UNAC (at the district and provincial levels) unions.

The other faction are those in the NPC, who have raised critical questions concerning the contradictions inherent in the Master Plan and the model of agricultural development it is predicated on. Their modes of outreach have been through the release of statements in Mozambique media, and holding regular strategy meetings. Apart from activists from the regular participating members, there was the participation of the President and Vice-President of UNAC and a former vice-president of Zambézia Peasant Union.

In the next section, we go over UNAC's foundational roots and principles, paying particular attention to the dynamics of its instrumental participation in the opposition and resistance to ProSAVANA.

\subsection{The role of the national peasant union (UNAC)}

\subsubsection{Roots and constituency}

When Mozambique was moving into a market economy through the adoption of IMF and the World Bank programs, peasants in various parts of Mozambique feared a possible disappearance of already established farmers cooperatives. This initiated the national movement to defend the interest of the peasantry. ${ }^{11}$ UNAC wanted to represent the voice of peasants, speaking out in defense of their social, economic and political interests, upholding a vision to attain sustainable development, promoting both qualitative and quantitative approaches to self-organization (Article 4, UNAC Constitution).

At the beginning of their establishment in 1987, one of UNAC's top priorities was the political organization and establishment of leaders within the member associations. This was based on the conviction that, in order for a national peasant movement to be politically strong, it should be politically trained. ${ }^{12}$

The relevance of UNAC is recognized starting with its considerable number of members (more than 100,000, according to the accounts announced in its last Electoral Assembly, in 2016), placing it as the largest organized social movement in Mozambique. UNAC is recognized as the organization that officially speaks on behalf of the peasantry in Mozambique. This is regardless of whether those represented by it are actually affiliated to UNAC as members. ${ }^{13}$ Hence, the Mozambican Ministry of Agriculture necessarily considers UNAC as their strategic partner (MASA, website 2018).

\footnotetext{
${ }^{11}$ Interview, Ismael Oussemane, honorary president and co-founder of UNAC. March, 2017.

${ }^{12}$ Interview, Ismael Oussemane, honorary president and co-founder of UNAC. March, 2017.

${ }^{13}$ This statement was confirmed on several occasions by government officials themselves, when speaking in meetings with UNAC.
} 
Historically, the first popular organizations in Mozambique, i.e. of women, youth, workers and teachers, were initiated by FRELIMO. It is, therefore, significant that UNAC was one of the few organizations that formed outside the strict boundaries of FRELIMO (Negrão 2002; Monjane 2016). As a national movement, UNAC membership was strongly influenced by the political undercurrents of rural Mozambique. When UNAC was first established, RENAMO supporters dominated rural areas in central and northern regions of Mozambique. On the other hand, those in the southern regions strongly supported FRELIMO. The north's aversion to FRELIMO's policies may have been a key factor preventing FRELIMO from controlling the peasant movement.

UNAC could be seen as the microcosm of the peasantry in Mozambique: diverse, complex and clearly divided politically. Historically the peasantry was at the center of disputes in Mozambique: between the colonial regime and the liberation movement (liberation war); between the state forces and the RENAMO guerrilla (civil war); and today between FRELIMO and RENAMO parties (electoral battles). As Table 1 shows, it is mostly in the countryside where we observe significant fluidity in electoral support between FRELIMO and RENAMO. Differences in political views within UNAC are therefore so evident that it was decided that debates of a political-partisan nature within the movement have to be avoided in order to avoid fragmentation (interview, Ismael Oussemane, 2017).

\subsubsection{UNAC and ProSAVANA}

At the beginning, UNAC attempted to be intimate with the then Ministry of Agriculture and ProSAVANA officials. This tactic, however, did not succeed in influencing the Government's decisions. Luís Muchanga, the current Director of UNAC, described the initial interactions:

There was some authoritarianism then, and it was felt in several ways; even in conferences, we (UNAC and the Government) had some clashes, and there were threats, even to the previous President of UNAC ... maybe because there is the assumption that civil society is against the Government, and if the person disagrees with me, even if it is a good idea, there is a blockage, just because it is divergent. ${ }^{14}$

The first UNAC official statement on ProSAVANA was issued in October 2012, after a meeting held in Nampula, which aimed at discussing and analyzing ProSAVANA. It was strongly critical of the program, stating 'we strongly condemn any initiative that calls for the resettlement of communities and expropriation of peasants' land, in order to give way to mega agricultural projects for monocultural production' (UNAC 2012). The statement emphasized that the Provincial UNAC Unions of Nampula, Zambézia, Niassa and Cabo Delgado were skeptical about ProSAVANA. Their statement posed that opposing ProSAVANA was a decision of 'all members of the National Union of Peasants' (UNAC 2012).

It was only later, however, that the movement truly started to engage with its membership base on ProSAVANA, starting mainly with the leaders of district and provincial unions. This implies that the official UNAC position on ProSAVANA was not necessarily reflective of all of its members' deep understanding of the issue. This was evidenced by the lack of

\footnotetext{
${ }^{14}$ Interview, Luís Muchanga, Director President of UNAC, member of NPC, 30 August 2018.
} 
consistency in opinions given regarding ProSAVANA among UNAC members. While the leadership of UNAC provincial unions in Nampula and Zambézia were consistent in their oppositions against ProSAVANA, at the individual level, there were some emerging opinions in favor of it.

Literature on social movements and peasant agency suggests that there is often a distance between movements and their base (Edelman 2017). This can, to some extent, be the case of UNAC, regarding ProSAVANA. It is worth noting, however, that people strongly questioning ProSAVANA at public hearings and consultations were not limited to peasants who are aligned with UNAC and NPC. This shows that opposition to ProSAVANA has been actually wider and beyond the scope of the known actors.

Nonetheless, the participation of UNAC and its leadership role in the opposition to ProSAVANA was essential in giving legitimacy to NPC, even after the fragmentation of civil society into two opposing groups. After a recently held meeting in March 2019, which was convened by the current minister of MASA to reach consensus among civil society and de-hibernate ProSAVANA, both NPC and UNAC (in a separate statement) released statements reiterating their opposing position.

\subsection{Key strategies of NPC that resulted in the stagnation of ProSAVANA}

The stagnation of ProSAVANA can be explained from a combination of tactics intrinsic to the NPC. We developed these into five elements: (1) active agency from below, (2) intersector civil society alliance, (3) communication, publicity and media strategy, (4) transnationalization of the struggle and (5) proposal of alternatives confronting dominant narratives. These elements are considered against a backdrop of external factors which include the political and economic environment within Mozambique and in the external investor countries. We do not claim this set of strategies, some of them mere activities, to be a formula to guarantee 'success' in resisting agrarian authoritarianism. The goal is to show in detail what ProSAVANA opponents have done, in terms of actions and activities, to hibernate it, which is relevant enough to the understanding of the outcome of the resistance process, particularly in the case of Mozambique.

\subsubsection{Active agency from below}

The debate about the various political reactions from below towards land grabbing, initiated by Borras and Franco (2013), directly relates to the resistance processes regarding the ProSAVANA case. This was the unique factor that quickly brought strength and legitimacy to the opposition of ProSAVANA; and it framed the determination of UNAC to lead the process of resistance. Peasant protests, however, were not limited to UNAC members. This was exemplified during the Mutuale public hearing which took place in Malema District, Nampula Province. A peasant protested against the implementation of ProSAVANA (ADECRU 2015):

We, in Mutuale, do not want ProSAVANA because this program does not represent the interests of the peasants. We know that with this program, we will lose our land. We know that the peasants will be forced to go ask for land in other places as it is happening now with the people who were expelled from their land when the AGROMOZ company entered, in the Gurué District, Administrative Post of Lioma. Today, those people left there are coming to 
ask for places to live here in Mutuale. We do not want to go asking for land in other communities because this will later bring conflict between us

With no satisfactory response from the proponents of ProSAVANA, peasants decided to walkout of the meeting. This was because peasants from this particular area were previously exposed and had access to information translated into their local language in the form of videos and leaflets, which helped them to clearly understand the risks, which shaped their opinions about ProSAVANA.

When asked why he is saying no to ProSAVANA, a peasant member of UNAC, from Muecate district in Nampula province, responded with the following:

... from the information that we had access to, regarding Prodecer in Brazil and its impacts, they tried to take away Brazilian peasant's land, and now those projects are being transferred to Mozambique ... Being a less developed country compared to Brazil, we think that we cannot accept that project, one day it will harm us. They occupy extensive areas, so we don't have enough space to do our machambas [family farm land], this was one reason to say no to ProSAVANA. We have the capacity to work, but they cannot come and harm us in our life, that lead us to say no to ProSAVANA and we will continue to say so. ${ }^{15}$

Such statements are reflective of UNAC having taken the lead and released a statement of concern at an early stage, allowed political reactions from below to take emerge. Very quickly, local associations, district and provincial unions of UNAC were mobilized. This crippled the efforts for the proponents of ProSAVANA, including local government, to convince the peasantry of its 'benefits'. This strong position of UNAC and peasants on the ground, however, did not quite overcome the authoritarian position of the Mozambican Government. The government remained unphased by protests. This, however, contributed to the extend efforts to cooperate between different sectors of society.

\subsubsection{Inter-sector civil society alliance and segregated processes of resistance}

The segregation of struggles and movements has been very common among Mozambique civil society groups and has long contributed to the segregated processes of resistance and focus of social change among social movements and activists. Historically, urban-based struggles have had little dialogue with rural-based struggles. Trade unions have had little dialogue with peasant/agrarian organizations. Similarly, advocates of women and gender issues have had very little dialogue with those working on housing, transportation, and environmental issues.

The first notable exception was the Land Campaign (Campanha Terra), which was one of the few active inter-sectoral groups to build an advocacy and debate platform to include popular views and defend the interest of the peasantry in the 1997 Land Law. At the beginning, the Land Campaign was not coordinated. According to Negrão (2002, 18) 'there were fundamental concerns covering a wide spectrum of layers and groups of social interests,' bringing together 'churches, associations and cooperatives, non-governmental organizations, academics, politicians and even elements in the private sector, in addition to dozens of incognito honest citizens'. Once the 1997 Land Law was passed, the Land Campaign declined. Nevertheless, the issue of land, particularly losing land for capital grab in Mozambique remained a compelling issue for mobilization.

\footnotetext{
${ }^{15}$ Interview, peasant Member of UNAC Nampula, District of Muecate, February 2017.
} 
Following the Land Campaign, different sectors of the Mozambican civil society created synergies that fed the growth and legitimacy of the fight for environmental, land, agrarian and gender issues as one big and cohesive cause. Following this trend, NPC has arguably been one of the most innovative and effective alliance among different constituencies, which paved the way for ProSAVANA to be perceived as an important national issue, garnering public interest.

This demonstrates that land is a highly sensitive and potent issue in Mozambique. Defending it is associated with people's sovereignty, and losing it triggers memories of colonialism and vulnerability. This makes the agrarian question in Mozambique transversal to many other national concerns. It is important to note that many academics and civil society organizations, including members of parliament, not associated with NPC, also publicly presented critical assessments of ProSAVANA's Master Plan, its discourse and how the program itself was problematically being introduced.

\subsubsection{Communication, publicity and media strategy}

One of the main strengths of NPC can be attributed to the designing of an effective communication and media strategy. The use of online communication channels, from websites and blogs to social media, as well as local newspapers, has been a dominant tactic. The campaign would publish on a regular basis, and openly disclosed statements, testimonies, articles, videos and images (photos and infographic material) highlighting resistance to ProSAVANA, exposing its negative social and environmental issues. This can be attributed to the extensive communication and media experience held by NPC members, providing effective access to tools and existing networks to disseminate information.

The NPC publications were shared amongst the websites managed by the various participating members not only in Mozambique, but in Brazil and Japan. Social media was also actively utilized, where links to the publications and key messages were shared on the campaign's facebook page, which had more than one thousand followers as of January 2018. ${ }^{16}$ Additionally, campaign materials were quickly republished through other media outlet websites, including media organizations such as Pambazuka News (2016). NPS media strategy included getting the issue into local and international mainstream media. As a result, leading international newspapers, such as The Guardian (2014), Neues Deutschland (2018) and Deutsche Welle (2017), published stories mentioning the resistance to ProSAVANA.

\subsubsection{Transnationalization of the struggle and solidarity mobilization}

The involvement of Brazil and Japan's social movements/civil society in ProSAVANA resistance inspired international solidarity. Almost all of the main Brazilian agrarian movements associate with La Via Campesina Brazil, and a number of progressive NGOs, such as GRAIN, and progressive intellectuals in Japan were supporting the Campaign. Since 2014, a number of activities - such as 'lobbying' meetings in Brazil - have been carried out in their respective countries, as a strategy to put pressure on EMBRAPA in Brazil and JICA in Japan and, wherever possible, to identify allies inside those institutions. This was particularly effective in Japan, where their lobbying and advocacy actions at the parliament level resulted in a strong alliance between Japanese organizations and a left-wing

\footnotetext{
${ }^{16}$ The facebook page was opened in 2016.
} 
parliamentarian who pushed for fierce debates on ProSAVANA. It was through this alliance that ProSAVANA was strongly debated at Japanese parliament.

Institutional impacts in Brazil have been harder to monitor. What is noteworthy, however, is the progressive decline of Brazil's institutional involvement in the current developments of the program. Contributing factors may be the political and economic events that have taken place during the last three years, namely the deepening economic crisis, the impeachment of President Dilma Rousseff, and the election of a right-wing government that openly announced shifting its foreign policy to focus on the Global North.

Regardless, a defining factor is how some Mozambican organizations in NPC have been active members of some of the largest and most radical transnational social movements in the world. In particular, UNAC is a member of La Via Campesina, Fórum Mulher is a member of, and hosting, the World March of Women, and Justiça Ambiental is a member of Friends of the Earth International. With its established global network, these movements are known for their capacity to mobilize global solidarity, attract media attention, and give global visibility to local struggles.

\subsubsection{Alternative proposals confronting dominant narratives}

UNAC has been credited for establishing a constructive form of resistance led by the people, contesting the model of development proposed in ProSAVANA with a clear proposition of an alternative on the table. To this end, agroecology, as a strategy, has guided UNAC's agenda since the design of its 2011-2015 Strategic Plan.

We remain firmly committed to peasant farming and agroecology - the foundations of Food Sovereignty - as alternatives to the development of the agricultural sector in Mozambique, which consider all aspects of sustainability and are, in practice, friends to nature. (UNAC 2012)

In its current 2015-2020 Strategic Plan, agroecology is mentioned under the 'Advocating Peasant's Rights' pillar of the plan in which UNAC assumes agroecology as the main mechanism through which food sovereignty is going to be achieved in Mozambique. In almost all statements of NPC, it is made clear that rejecting ProSAVANA was not just an end in itself. Proposals such as Agroecology and Food Sovereignty were given as practical alternatives to what ProSAVANA proposed, which were based on agribusiness, monoculture, land reserves, global markets, and intensified production. In recent years, UNAC has actively been engaging its members in specific educational and training programs on agroecology. Furthermore, the movement has been successful in building an Agroecology School in the Manhiça District (South of Mozambique) and training rural extensionists in agroecology throughout the country (three promoters per province who conduct trainings at the village level). For example, in the Marracuene District, 285 peasants were trained on agroecology as a pilot project. Lastly, exchanging visits and experiences between peasant associations have also been influential in the promotion of alternative narratives of development. $^{17}$

Another experience worth highlighting is the Alfredo Nhamitete Agricultural Association, in the district of Marracuene, Maputo province. Their 280 members produce various food crops, some of which they sell at the local market. Income is shared equally among members (LVC Africa News 2014). Several peasants began an exchange

${ }^{17}$ Interview, Renaldo João, peasant member of UNAC, 4 September 2018. 
with a peasant organization in Brazil, the Small Farmers Movement (MPA), to rescue seeds that are at risk of extinction, which are deemed to be of greater importance for food sovereignty. This exchange led to increased local seed sovereignty, drastically reducing the cost of seed procurement.

The growing number of peasants at the national level who are practicing agroecology and challenging the large-scale capitalist farming model, like ProSAVANA, should be seen as emancipatory. This combination of words followed by action has given strength to NPC.

\subsubsection{External factors: political and global economic environment}

A number of factors that were out of the control of the movement and the resistance actors could have directly or indirectly contributed to the strength of the resistance process. At the national level, the rising disapproval of the local government, due to overlapping crises, can be seen as the emergent localized ruptures with the authoritarian populist FRELIMO regime, especially in the areas where ProSAVANA is to be implemented. On an international scale, the political climate, both in Brazil and Japan, should be considered as a potential factor in the stagnation of the program. Additionally, the trends of commodity prices should be analyzed in order to fully understand the behavior of potential investors for ProSAVANA. Although it is difficult to have a comprehensive analysis of how these factors might have influenced the stagnation of ProSAVANA, the important points are summarized.

4.4.6.1. Overlapping crises and the rise of localized government unpopularity. The process of discussion and resistance to ProSavana was characterized by a parallel emergence of political and military crises that consequently contributed to the escalation of the economic crisis in Mozambique. These events derived from a combination of micro and macro issues of political and economic instability such as unjust resettlements of peasants due to the development of extractive industries and agricultural investments, the uncovering of hidden and illegal public debt involving ministers, along with both the current and former presidents, alongside the rising discontent of the RENAMO Party, and competition over the control of the resource-rich regions. This resulted in recurrent armed conflicts in rural areas. Needless to say, rural inhabitants and peasants were economically affected. The state, however, was slow in controlling this social instability.

As mentioned previously, the localized decrease of FRELIMO's popularity, specifically in rural areas, can be explained by the increased implementation of land-based agricultural investments that resulted in the expropriation of people's land in Zambézia, Nampula and Niassa Provinces, where a number of companies expropriated hundreds of thousands of hectares from local peasants (UNAC \& GRAIN 2015; Bruna 2017; Mandamule and Bruna 2017).

As shown in Table 1, FRELIMO has been losing votes since 2008. In 2018, RENAMO got more votes in many of the districts in these three provinces, including Malema District, which was one of the regions where peasants were contesting the most, due to ongoing ProSAVANA activities. It is also important to take into consideration that, for the first time, RENAMO was able to get $49 \%$ of the total votes on the national level. This means that for the last decades, FRELIMO's political dominance has been decreasing as RENAMO's has been increasing. 
The importance of analyzing the political context in which the process of resistance happened is because it contributed to the increase of awareness of FRELIMO's failure in adopting a socially just development model for both rural and urban contexts. This, then, facilitated and/or motivated the engagement of peasants in the struggle. This fact marked the transformation of the roots of rural Mozambique's typical way of resistance, which had been characterized up to this point by Scott's (1986) everyday forms of resistance until the incorporation of an overt and semi-organized way of protesting as was verified in the case of ProSAVANA.

4.4.6.2. Brazil's political instability and Japanese democracy. As Brazil's political crisis emerged in the last years, the Brazilian Cooperation Agency's ( $A B C$ ) role in the implementation of ProSAVANA has been decreasing, especially in terms of degrees of involvement in the responses to the program's resistance movement. Contrary to this position, the Japanese Cooperation Agency (JICA) took the lead in attempting to revise the program's Master Plan, claiming to be open, to a certain degree, to negotiate its terms and integrate civil society's demands. They were even willing to finance the formation of an integrated organization to manage all civil society claims regarding the implementation and revision of the Master Plan.

It is relevant to consider the role of the Japanese parliament and democracy in relation to the process of resistance against ProSavana. More than cooperating with the struggle in Mozambique, the pressure exercised by the Japanese civil society towards the Japanese parliament directly reflected on the decision-making process of JICA. This would consequently compel the Mozambican Government to give in, given the power relations existing between the two nations, that of beneficiary and donor. Despite its controversies, the democratic system in Japan is operating at a much higher degree than in Brazil or Mozambique. Hence, the existing 'democratic regime' in Mozambique is less reliable than in Japan.

4.4.6.3. Global economic environment: commodity prices trends. Since ProSAVANA's implementation was contingent upon the support of both internal and external investors, the investment decision would inevitably rely on global trends of commodity prices. The Master Plan identifies two main crops as 'priority crops' to be promoted by the program, namely maize and soya. Looking at the international price of maize (Index Mundi 2019), the trends show high prices for the period between 2011 and 2013, with a peak of approximately 330USD per metric ton between July and August of 2012. This is followed by sharp decreases in late 2013, reaching the lowest point in 2017, priced at 150USD per metric ton.

Regarding the international price of soybeans (Index Mundi 2019), rising prices were observed in the beginning of the 2000s reaching a maximum of 684USD per metric ton in August 2012, a period in which ProSAVANA discussions were still ongoing far from the public eye. This was followed by some fluctuations in price between late 2012 and 2014. In mid 2014 the price started to significantly decrease, until reaching the lowest point in early 2016 at 370USD per metric ton. When taking into account the factors influencing the decision-making process for investors, we could observe a significant decrease in the international price of both priority crops by approximately $50 \%$ throughout the period during which the ProSAVANA resistance movement was taking place. 


\section{Concluding remarks}

The failure of grasping the nature of the agrarian question in Mozambique rests in the fact that Mozambique has been governed by a persistent authoritarian regime with oscillating levels of populism, which tended to impose agrarian policies that prioritize large scale investments to the detriment of peasants. The achievement of national independence by a revolutionary force, whose populist claims for ending Portuguese colonial continuities and subsequently fighting a guerilla counter-movement were both used to build and sustain its political power and influence.

This paper highlighted problems surrounding the planning and implementation of ProSAVANA, starting with the approaches taken to hold public hearings. This was followed by the deviations of ProSAVANA's Master Plan, its proposed guidelines, which was contributing to the expropriation of land, the intensification of debt among peasants, and the promotion of crops that do not answer to people's needs. The persistent lack of transparency and little or no regard for public participation were at the core of these issues. It was in this context that the resistance process took place with NPC as the leading force and UNAC as the main element of legitimation.

Confronting agrarian authoritarianism may go beyond the intrinsic boundaries of a campaign. There are factors that are beyond the control of a specific movement, but still a determinant for its success. Although FRELIMO lost its popularity because of its own failure to deliver and to meet people's expectations, it reacted with higher levels of authoritarianism and, consequently, it lost a big share of its electoral votes. Nevertheless, we argue that it is important to acknowledge that this kind of rupture in the dominant political force could be a window of opportunity to effectively confront authoritarianism. In this case, progressive populism arose as a strategic response of the resistance process. NPC upheld a clear agenda: demanding that ProSAVANA stop immediately and indefinitely through proposing an alternative model of development.

The set of strategies and tactics that gave strength and cohesion to the NPC, discussed above, was built into a unified agenda against the proposed model of development. The strong ideological bond among all of the transnational members of the campaign allowed them to constitute a narrative of 'us against them', othering, in this case, the proponents of ProSAVANA. Moreover, NPC discourses were highly anti-capitalistic and with a strong position toward an alternative paradigm of development, referred to as the 'peasant way' and 'agroecology'. This is in line with what Borras (2019) called agrarian populism, or a form of progressive populism. The outcomes of the resistance process were not only the current stagnation (not yet a discontinuation) of the ProSAVANA project, but also the expanded space for discussion and participation among peasants and civil society throughout the decision process.

Overall, this paper addressed the process and dynamics of resistance to ProSAVANA as a way of confronting authoritarian imposition of agrarian policies in Mozambique. It portrays how the process of building a unified and coherent resistance movement transformed the Mozambican civil society into a more mature, consolidated and dynamic civil society. Moreover, it argues that by identifying breaks and/or rifts in the authoritarian populist regime, such as the decrease of FRELIMO's popularity, they can be used against the regime itself and increase the effectiveness of the campaign's strategies and give more fluidity for the resistance process itself. 


\section{Acknowledgments}

The authors wish to thank Mai Kobayashi and Amanda Kobayashi for their kindness in proofreading the manuscript. We are also grateful for the helpful comments of the anonymous reviewers. All possible errors remain ours. The authors would also like to thank the Rosa Luxemburg Foundation and the Institute for Poverty, Land and Agrarian Studies in the context of the Emancipatory Rural Politics Initiative (ERPI) for the small research grant provided.

\section{Disclosure statement}

No potential conflict of interest was reported by the authors.

\section{ORCID}

Boaventura Monjane (D) http://orcid.org/0000-0002-8944-629X

\section{References}

ADECRU. 2014. "Lançada campanha NÃO AO PROSAVANA em Moçambique." Blog Article. Accessed March 21，2019. https://adecru.wordpress.com/2014/06/02/lancada-campanha-nao-aoprosavana-em-mocambique/.

ADECRU. 2015. "Comunidades rejeitam a implementação do ProSAVANA e abandonam a sala de reunião de auscultação pública em Malema." Accessed March 21, 2019. https://adecru. wordpress.com/2015/04/30/comunidades-rejeitam-a-implementacao-do-prosavana-eabandonam-a-sala-de-reuniao-de-auscultacao-publica-em-malema/ and https://www.jpic-jp.org/ es/w/3547-comunidades-rejeitam-a-implementa-o-do-prosavana-e-abandonam-a-sala-de-reunio-de-ausculta-o-p-blica-em-malema.

Bennett, A., and A. L. George. 2005. Case Studies and Theory Development in the Social Sciences. Cambrige: MIT Press.

Borras, J. 2019. "Agrarian Social Movements: The Absurdly Difficult but Not Impossible Agenda of Defeating Right-Wing Populism and Exploring a Socialist Future." Journal of Agrarian Change 2019: 1-34.

Borras, S., and J. Franco. 2013. "Global Land Grabbing and Political Reactions 'From Below'." Third World Quarterly 34 (9): 1723-1747.

Bruna, N. 2017. "Plantações florestais e instrumentalização do Estado em Moçambique." Observador Rural. No. 53. Maputo.

Byres, T. J. 1991. The Agrarian Question and Differing Forms of Capitalist Agrarian Transition: An Essay with Reference to Asia. Rural Transformation in Asia, 3-76.

Chichava, S. 2016. "A sociedade civil e o ProSAVANA em Moçambique." In Desafios para Moçambique 2016, IESE.

Clements, E. A., and B. M. Fernandes. 2013. "Land Grabbing, Agribusiness and the Peasantry in Brazil and Mozambique." Agrarian South: Journal of Political Economy 2 (1): 41-69.

Coelho, J. P. B. 1998. "State Resettlement Policies in Post-colonial Rural Mozambique: The Impact of the Communal Village Programme on Tete Province, 1977-1982." Journal of Southern African Studies 24 (1): 61-91.

Comboni Missionaries. 2015. Accessed September 18, 2019. https://www.comboni.org/contenuti/ 107523.

Comissão Nacional de Eleições. 2018. "Autárquicas 2018." Accessed August 8, 2019. http://www. open.ac.uk/technology/mozambique/sites/www.open.ac.uk.technology.mozambique/files/files/ Resultados\%20e\%20mandatos\%202018.pdf.

CPI (Centro de Promoção ao Investimento). 2017. Investimento aprovado [Data Base], June, 2017. Maputo: CPI. 
Deutsche Welle. 2017. "Moçambique: Investigação à JICA no caso ProSavana vista como conquista na luta contra o projeto." Accessed September 18, 2019. http://www.dw.com/pt-002/mo\%C3\% A7ambique-investiga\%C3\%A7\%C3\%A3o-\%C3\%A0-jica-no-caso-prosavana-vista-comoconquista-na-luta-contra-o-projeto/a-39648276.

Edelman, M. 2017. Activists empedernidos e intelectuales comprometidos: ensayos sobre movimientos sociales, derechos humanos y studios lationoamericanos. Quito: Instituto de Altos Estudios Nacionales.

FGV. 2012. "FGV Projetos e GVAgro lançam Fundo Nacala nesta quarta-feira, em Brasília." Accessed September 18, 2019. https://portal.fgv.br/noticias/fgv-projetos-e-gvagro-lancam-fundo-nacalanesta-quarta-feira-brasilia.

Funada-Classen, S. 2013a. "Anatomia Pós-Fukushima dos Estudos sobre o ProSAVANA: Focalizando no 'Os mitos por trás do ProSAVANA' de Natalia Fingermann." Observador Rural No 6. Observatório do Meio Rural. Maputo.

Funada-Classen, S. 2013b. Analysis of the Discourse and Background of the ProSAVANA Programme in Mozambique - Focusing on Japan's Role. Tokyo: Tokyo University of Foreign Studies.

Garcia, F. P. 2001. "Análise global de uma guerra (Moçambique 1964-1974)." PhD., Universidade Portucalense, Porto.

The Guardian. 2014. "Mozambique's Small Farmers Fear Brazilian-style Agriculture." Accessed September 18, 2019. https://www.theguardian.com/global-development/2014/jan/01/ mozambique-small-farmers-fear-brazilian-style-agriculture.

Hadiz, V. R., and A. Chryssogelos. 2017. "Populism in World Politics: A Comparative Cross-Regional Perspective." International Political Science Review 38 (4): 399-411.

Hall, S. 1980. "Popular-Democratic Versus Authoritarian Populism." In Marxism and Democracy, edited by A. Hunt, 157-187. London: Laurence and Wishart.

Hall, S. 1985. "Authoritarian Populism: A Reply to Jessop et al." New Left Review 151: 115-124.

Index Mundi. 2019. "Commodity Prices." Accessed September 18, 2019. https://www.indexmundi. com/commodities/.

Inocêncio, M. E. 2010. "PROCEDER and the Wefts of Power in the Territorial Capital in the Cerrado. 2010. 271 f." PhD., dissertation. Doctorate in Humanities - Universidade Federal de Goiás, Goiânia.

Instituto Nacional de Estatística. 2018. Produto Interno Bruto [Data Base], July 2018. Maputo: INE.

JCC. 2012. Triangular Cooperation for Agricultural Development of the Tropical Savannah in Mozambique (ProSAVANA JBM): Support of Agriculture Development Master Plan for Nacala Corridor. Power Point Presentation: The third JCC, Nampula, Mozambique, 2013.

Justiça Ambiental et al. 2013. "Leaked Copy of the Master Plan for the ProSAVANA Programme in Northern Mozambique Confirms the Worst: Civil Society Groups Warn Secretive Plan Paves the Way for a Massive Land Grab." Civil Society Joint Statement. Accessed March 20, 2019. https:// www.grain.org/media/W1 siZilsljlwMTMvMDQvMzAvMDhfMzZfNDhfN19Db2xsZWN0aXZIX3N0Y XRlbWVudF9vbl9NYXN0ZXJfUGxhbl9BcHJpbF8yOV9GSU5BTDlucGRmll1d.

Lourenço, V. A. 2010. Moçambique: Memórias sociais de ontem, dilemas políticos de hoje. Segunda edição ed. Lisboa: ISCTE-IUL.

LVC Africa News. 2014. "Mozambique: 'Agroecological farming came to stay in Marracuene' — say the farmers." Accessed September 24, 2019 https://viacampesina.org/en/mozambique-agroecologicalfarming-came-to-stay-in-marracuene-says-the-farmers/.

Mandamule, U., and N. Bruna. 2017. "Investimentos, migrações forçadas e conflitos de terra: representações sociais de populações reassentadas no Corredor de Natal." In Movimentos migratórios e relações rural-urbanas: estudos de caso em Moçambique, edited by j. Feijó. Maputo: Alcance Editores.

MASA. 2015. "Plano Director para o Desenvolvimento Agrário do Corredor de Nacala em Moçambique." Esboço Versão 1-39. (Maputo).

Melber, H. 2018. "Populism in Southern Africa under Liberation Movements as Governments." Review of African Political Economy 45 (158): 678-686.

Mello, P. C. 2011. "Moçambique oferece terra à soja brasileira." Folha de S. Paulo, August 14. 
Moçambique para todos. 2015. "Irritada com ameaças de Pacheco, Sociedade Civil abandona sala de debate." Accessed September 18, 2019. https://macua.blogs.com/moambique_para_todos/2015/ 06/irritada-com-ameaças-de-pacheco-sociedade-civil-abandona-sala-de-debate.html.

Monjane, B. 2015. "Auscultação pública sobre o ProSAVANA: Ministro exige intervenções 'patrióticas' e activistas abandonam a sala." Reflectindo sobre Moçambique. Accessed September 18, 2019. http://comunidademocambicana.blogspot.com/2015/06/auscultacao-publica-sobre-o-prosavana. html.

Monjane, B. 2016a. "Movimentos sociais, sociedade civil e espaço público em Moçambique: uma análise crítica." Cadernos CERU 27 (2): 144-155.

Monjane, B. 2016b. "Reagrupar para controlar? Uma análise crítica das políticas Estatais de organização coerciva das populações rurais em Moçambique." Revista Educação e Políticas em Debate 5 (1): 84-94.

Monjane, B. 2017. "ProSavana: Mozambique's Civil Society Demands the Immediate Suspension of the Actions of JICA." The Dawn. Accessed September 18, 2019. http://www.thedawn-news.org/ 2017/02/24/prosavana-mozambiques-civil-society-demands-the-immediate-suspension-of-theactions-of-jica/.

Mosca, J. 2005. Economia de Moçambique: Século XX. Lisboa: Instituto Piaget.

Mosca, J., e N. Bruna. 2015. "ProSAVANA. Discursos, práticas e realidades." Observador Rural No 31. Observatório do Meio Rural. Maputo.

Negrão, J. 2002. "A indispensável terra africana para o aumento da riqueza dos pobres." Centro de Estudos Sociais. Accessed September 18, 2019. http://www.ces.uc.pt/publicacoes/oficina/ ficheiros/179.pdf.

Neues Deutschland. 2018. "Mosambiks Kleinbauern müssen gegen die Interessen der Agrarmultis verteidigt warden." Accessed September 18, 2019. https://www.neues-deutschland.de/artikel/ 1075801.nd-soliaktion-teilen-macht-satt-umkaempftes-saatgut.html.

O'Laughlin, B. 1996. "Through a Divided Glass: Dualism, Class and the Agrarian Question in Mozambique." The Journal of Peasant Studies 23 (4): 1-39.

Pambazuka News. 2016. Accessed September 18, 2019. https://www.pambazuka.org/landenvironment/mozambique-government-not-sincere-about-prosavana.

Pitcher, M. A. 2012. Transforming Mozambique. The Politics of Privatization, 1975-2000. Cambridge: Cambridge University Press.

República de Moçambique. 2011. Plano Estratégico para o Desenvolvimento do Sector Agrário (PEDSA). Maputo: Ministério da Agricultura.

Scoones, I., M. Edelman, S. M. Borras Jr, R. Hall, W. Wolford, and B. White. 2017. "Emancipatory Rural Politics: Confronting Authoritarian Populism." The Journal of Peasant Studies 45: 1-20.

Scott, J. 1986. "Everyday Forms of Peasant Resistance." The Journal of Peasant Studies 13 (2): 5-35.

Shankland, A., and E. Gonçalves. 2016. "Imagining Agricultural Development in South-South Cooperation: The Contestation and Transformation of ProSAVANA." World Development 81: 35-46.

Shivji, Issa G. 2019. "Sam Moyo and Samir Amin on the Peasant Question." Agrarian South: Journal of Political Economy 8: 1-16.

UNAC. 2012. "Pronunciamento da UNAC sobre o Programa Prosavana." Nampula, de Outubro 11.

UNAC e GRAIN. 2015. Os usurpadores de terras do Corredor de Nacala. Uma nova era de luta contra plantações coloniais no Norte de Moçambique. Maputo: UNAC e GRAIN.

UNAC, et al. 2013. "Open Letter from Mozambican Civil Society Organizations and Movements to the Presidents of Mozambique and Brazil and the Prime Minister of Japan." Accessed Auguest 13, 2019. https://www.grain.org/bulletin_board/entries/4738-open-letter-from-mozambican-civilsociety-organisations-and-movements-to-the-presidents-of-mozambique-and-brazil-and-theprime-minister-of-japan.

WLSA Moçambique. 2014. “Eleições autárquicas de 2013." Accessed August 8, 2019. http://www.wlsa. org.mz/wp-content/uploads/2014/11/Eleicoes2013_anexos.pdf.

Wolford, W., and R. Nehring. 2015. "Constructing Parallels: Brazilian Expertise and the Commodification of Land, Labour and Money in Mozambique." Canadian Journal of Development Studies/Revue Canadienne D'études du Développement 36 (2): 208-223.

Wuyts, M. 2001. "The Agrarian Question in Mozambique's Transition and Reconstruction." Discussion Paper, 14. United Nations University. 
Boaventura Monjane is a PhD candidate at the Centre for Social Studies, University of Coimbra and associate researcher at the Sam Moyo African Institute of Agrarian Studies. He is currently a visiting researcher at the International Institute of Social Studies, Erasmus University Rotterdam in The Hague. His areas of research include: agrarian social movements, agrarian political economy, climate change and 'alternatives from below'.

Natacha Bruna is currently a PhD candidate in the International Institute of Social Studies (Erasmus University Rotterdam) on the Political Ecology research group. Her research is about the agrarian change brought up by the intersections of resource grabbing as a result of extractivism and environmental politics. She is currently engaged as a researcher in an independent research institution in Mozambique - Observatório do Meio Rural (www.omrmz.com). Her areas of research include: agrarian political economy, political ecology and extractivism. 